\title{
IDIOSINKRETIVITY OF ADATRECHT ON THE FORMAT DEMOCRACY IN INDONESIA
}

\author{
*Rizki Yudha Bramantyo ${ }^{1)}$, Satriyani Cahyo Widayati ${ }^{2)}$ Niniek Wahyuni $^{3)}$, Bambang \\ Pudjiono $^{4}$ \\ 1) Program Studi Ilmu Hukum Fakultas Hukum Universitas Kadiri \\ Indonesia \\ 2) Program Studi Ilmu Hukum Fakultas Hukum Universitas Kadiri \\ Indonesia \\ 3) Program Studi Ilmu Hukum Fakultas Hukum Universitas Kadiri \\ Indonesia \\ 4) Program Studi Ilmu Hukum Fakultas Hukum Universitas Kadiri \\ Indonesia \\ *Email Korespondensi : rizki_bramantyo@unik-kediri.ac.id
}

\begin{abstract}
The relationship between customary law and national law in the context of developing national law is a functional relationship, meaning that customary law is the main source in obtaining materials needed for the development of national law. Customary law that is needed in the era of globalization or modern times is customary law that is adapted to the conditions and developments of the times, so that customary law shows a dynamic nature so that it can easily develop according to the times because it has universal values and legal institutions. Which is in the form of a modern statement. With this adjustment, it is possible that the purity of the application of the rules of customary law to become national law will experience a shift, as long as it is to enrich and develop national law, as long as it does not conflict with Pancasila and the 1945 Constitution.
\end{abstract}

Keywords: Customary Law; National Law Development; Globalization.

\section{INTRODUCTION}

Amendments to the 1945 Constitution have embodied the Indonesian constitution which enables the implementation of a modern and democratic state administration. The spirit embodied in the amendment of the constitution is the supremacy of the constitution, the necessity and importance of limiting power, regulating relations and power between branches of state power more firmly, strengthening the system of checks and balances between branches of power, strengthening protection and guarantee of human rights, and 
regulating matters- fundamental things in various fields of life (Hardi, 2011). Moreover, today, democracy depicts social welfare as an indicator of success. Social welfare is an inseparable part of the ideals of independence and is an estuary of the economic development agenda (Anasiru, 2011)

Likewise, the ebb and flow of customary power in Indonesia affects the role of traditional leaders in the realm of politics and government. In the realm of government, traditional leaders play a role in the process of making a policy, just as in politics, sometimes (if needed) traditional leaders then appear in the community as an elite who is influential in the structure of society. The existence of indigenous peoples in several areas of the Republic of Indonesia is a nation's wealth that is unmatched by other countries. It is also important to pay attention to the existence of norms as part of the identity of indigenous peoples who form social capital. Whereas norms are formed through traditions, history, charismatic figures who build the behavior of a person or a community group, in which social capital will emerge spontaneously in the framework of determining rules that can regulate personal and group interests.

This existence can be seen from the socialization of a group of people calling themselves the Community Rights Defense Network consisting of traditional leaders, academics and activists in fighting for cultural identity and the rights of traditional communities being respected in line with the times and civilizations. The study of customary power (traditional leaders) becomes interesting and seems unique when faced with the power of the State, Religion and Adat as expressed by Longgina Novadona Bayo in her thesis entitled Adat Power over the Church and the State in Adonara (2010) shows that Adat is the central point in the life of the Adonara people. The state is no longer seen as having a central role in shaping social relations and social stratification, but the State must contest with social forces outside of the State body, in this case customs and churches (Polnaya \& Darwanto, 2015).

This is almost the same as Carol Warren's writing entitled Adat in Balinese Discourse and Practices: Positioning the Principle of Citizenship and Commonweal which pays special attention to the dualistic model of local government, namely official / adat villages, and on new legislation to correct weaknesses. customary institutions under the 
Bary Order regime: which built 'social capital', and its relationship with the gelao side of local empowerment and globalization. According to him, Balinese people increasingly recognize adat as a form of "capital" (capital), an asset that contributes to social, economic, welfare, aesthetic satisfaction and most importantly spiritual protection (Pramono et al., 2019). Even in Bali, indigenous communities play a more active role than the local government as they have done, namely sweeping street vendors in 1999, which is then considered capable of preventing inter-ethnic conflict during the tense situation after the 2002 bombings. In contrast to the local government which was less effective in resolving conflicts- In fact, the local conflict, the indigenous community, then appears as supralocal in Bali in solving the problems that occur.

In the end, locality is often positioned as a marginalized cultural entity, cornered by the roaming of global capitalism networks. One of the entities that are victims of marginalization is an entity or ethnic group. Something that is local in nature, the minority becomes an alienated item, rare so that it must be protected from extinction. The postmodernist movement which tends to take back the premodern paradigm presents itself as a movement back to nature, back to traditional customs, back to traditional wisdom. (Abdillah, 2002) However, not all regions in Indonesia highlight the influence of customs, traditional life, to local wisdom that characterizes each region, the identity of a region seems to be fighting with the government system and the influence of globalization that is about to take root in the joints of people's lives. Even so, resistance to ethnic identity has risen again with the presence of regional autonomy. The problem is, how is the existence of adat in the midst of globalization. As well as seeing the rise and role of ethnicity in the realm of government politics?

\section{LITERATUR REVIEW}

An anthropologist Ronald Niezen (in Davidson) reveals the origins and describes the development of a relatively new political identity known as indegeneity. The growth of the legitimacy of this identity flows from the strengthening of the international movement of indigenous peoples which is labeled indigenism (indigenm), which means the similarity of dire circumstances, namely marginalization, poverty, and cultural 
genocide among the very diverse populations of indigenous peoples around the world. Indigenous peoples are groups of people who have ancestral origins (from generation to generation) in a certain geographical area, and have their own value, ideological, economic, political, cultural, social and territorial systems. The result of the agreement of a Nusatara Indigenous Peoples Congress which was held in March 1999. The criteria for the community are (1) indigenous people; (2) minorities; and (3) the oppressed or marginalized because their identity is different from the dominant identity in a country or region. Another interpretation of indigenous peoples is people living in independent countries where their social, cultural and economic conditions distinguish them from other

parts of society in the country and their status is regulated, whether in whole or in part by indigenous peoples and traditions. The presence of the Indigenous Peoples' Alliance of the Archipelago (AMAN) gives hope to traditional leaders.

\section{Customary Institutions}

A customary institution is a social organization, either deliberately formed or which has naturally grown and developed in the history of the community concerned or in a certain customary law community with a legal area and rights to assets within the area of customary law, and has the right and authorized to regulate, manage and resolve various life problems related to and referring to prevailing customs and customary laws.

\section{Custom figures}

The term traditional leader began to be socialized in Indonesia after a group of people called themselves a network of advocating for community rights. customary figures are defined as people who live based on their ancestral origins over a customary area that has sovereignty over land and natural resources, then socio-culture is regulated by customary law and customary institutions, who manage and must know the ins and outs of their customary territory and the social culture and all customary regulations in this case traditional leaders are required to be able to be fair to all communities without having to differentiate from one another in any way in resolving a problem related to adat so that they can propose good deliberation and live in harmony between fellow communities. according to Maribet in the writings on Awakening of adat in West Flores "Culture, Religion and Land" divides the resurrection of customs into 3 (three) types: first, 
physical culture or material culture and performances. This is synonymous with art performances that are characteristic of a region and are shown in guest welcoming events. Second, the revival of religious rituals or ceremonies, especially for performances or also to affirm a regional identity or a distinctive or modern cultural identity. Third, the revival of adat includes customary institutions, this is related to political authority and also land tenure .

This third customary awakening can be felt when traditional leaders face political elites. The gloomy existence of adat during the New Order era due to regulations that suppressed customary rules made him return to his place in the reform era. Often customs are used as a tool in regulating people's lives so that they are used to mobilize the masses.

\section{RESEARCH METHOD}

This research uses a qualitative approach. This study also uses literature studies, literature studies are a method used to collect data or sources related to the topics raised in a study. Literature studies can be obtained from various sources, journals, documentation books, internet and libraries. The type of data used by the author in this study is primary data by conducting interviews and observations for two months, from November 2019 to December 2019 with a number of informants, namely community leaders involved in the Regional Head Election in Kediri Regency. This study also involved cultural observers and other community leaders who were purposive sampling. Then this study also uses secondary data, namely data obtained from journals, documentation books, and so on.

\section{DISCUSSION}

Discussing about the framework of the Unitary State of the Republic of Indonesia, of course we cannot let go of the existence of values, norms, rules and guidelines for behavior that live in society. These are the forms of the wealth of the Indonesian nation that have lived and developed for a long time in the lives of people in the archipelago. So it can be said that the values, norms, rules and guidelines for behavior can be said to be accommodated in a generally unwritten law which is widely known as customary law. 
In the literature, Snouck Hurgronje introduced the term Adatrecht (customary law) as the law that applied to the land of sons (native Indonesians) and foreign easterners during the Dutch East Indies era (Wahyuni, 2018). In addition, the same definition was put forward by Van Vollenhoven who defined customary law as the law applicable to the indigenous Indonesian people. So at least it can be understood that customary law is a law that lives in the midst of Indonesian society, and applies to Indonesian people, in which case each place of customary law has different arrangements but basically has the same conceptual roots.

Speaking of Indonesia as a rule of law, the existence of this customary law is also regulated, protected, and accommodated by the constitution. Referring to the provisions of Article 18B paragraph (2) of the 1945 Constitution regulates "The state recognizes and respects indigenous peoples and their traditional rights as long as they are still alive and in accordance with the development of society and the principles of the Unitary State of the Republic of Indonesia, which are regulated in law" . Referring to this provision, there are several important things that can be drawn from an understanding regarding the position of customary law in the Indonesian legal system.

Whereas the State recognizes the constitutional rights of indigenous peoples in Indonesia. And of course this includes the laws that live in it, namely the customary law itself. Recognition of these rights can be used as recognition of rights for indigenous peoples regarding their existence. In the sense that the customary law community is protected by the constitution, the existence of the community and everything that lives in the life of the community itself, including in this case the customary law itself which is part of the customary law community. In addition, recognition and respect for State law applies as long as customary law and the people themselves are still alive today. In the sense that the State's recognition should be a note for the Indonesian nation to always protect the preservation of indigenous peoples and their instruments as the noble heritage of the Indonesian nation that has gone through a long history plus the threat of degradation of indigenous peoples themselves currently in the midst of globalization and exposure.

It is also important to note that in connection with the constitutional foundation, this recognition is valid as long as these matters are in accordance with the development 
of society and the principles of the Republic of Indonesia itself. So in this case it seems not an exaggeration to mention that the State's recognition of customary law communities and the customary law itself is conditional recognition (even though in the concept of a State of law these conditions are a form of control over the rule of law).

If further investigated, as regulated in Article 4 of the Minister of Home Affairs Regulation No. 52/2014 concerning the recognition and protection of customary law communities, which in this case regulates the stages and conditions that must be met by the Customary Law Community to obtain legal certainty for their traditional rights. In these provisions, the customary community must go through stages that are carried out in stages to obtain legalization of recognition of the customary law community itself, where in this case the stages include the identification of indigenous peoples, verification and validation of the customary law community and then after 3 (three) these stages are passed, in this case the customary law community is determined as the output of these stages.

It is further stipulated that in the stage of identification of customary law communities, the things that become objects are the history of customary law communities, customary law, customary territories, customary assets and / or objects, institutions / customary government systems. Furthermore, in relation to customary territories and institutions / systems of customary governance, this legal provision is not yet regulated in a clear technical manner to determine how to determine customary territories controlled by customary law communities and or whether customary institutions / systems of governance are structurally regulated.

In the focus of the position of customary law in the Indonesian legal system, back to the constitution where the recognition of unwritten law was only explained or included in the General Explanation of the 1945 Constitution which in this case regulates "... The Basic Law is written basic law, while beside it. This Basic Law also applies to unwritten basic laws, namely basic rules that arise and are maintained in the practice of state administration even though they are not written. In the sense that customary law, which is generally unwritten, has the same position as other applicable laws in Indonesia considering the recognition of unwritten law in addition to the Basic Law itself. 


\section{CONCLUSION}

Customary law is a law that applies and develops in the community in an area. There are several definitions of customary law. According to M.M. Djojodiguno Customary law is a particular work of society which aims at a just order in behavior and actions in society for the welfare of society itself. According to R. Soepomo, customary law is an unwritten law which includes rules of life that are not stipulated by the authorities, but are obeyed by the community based on the belief that these regulations have legal force. According to Van Vollenhoven, customary law is the whole rules of positive behavior where on the one hand it has sanctions while on the other hand it is not codified. Meanwhile, Surojo Wignyodipuro provides a definition of customary law in general that is not written or not written, namely the complex of norms that are rooted in the feeling of justice of the people which is always developing including the rules of human behavior in everyday life, always obeyed and respected because it has legal consequences or sanctions. From the four definitions above, it can be concluded that Customary Law is an unwritten and uncodified rule, but is still obeyed in society because it has certain sanctions if it is not obeyed. From the definition of Customary Law stated above, the form of Customary Law is largely unwritten. In fact, in a constitutional state, a principle applies, namely the principle of legality. The principle of legality states that there is no law other than what is written in the law. This is to ensure legal certainty. But on the one hand, if the judge cannot find the law in written law, a judge must be able to find the law in the rules that live in society. Recognized or not, customary law also has a role in the National Law System in Indonesia

Customary law is a value that lives and develops in the community of an area. Although most of the Customary Laws are unwritten, they have a strong binding power in society. There are separate sanctions from the community for violating customary law rules. Customary law that lives in this society for people who are still thick with their original culture will be felt. The application of customary law in everyday life is also often applied by the community. Even a judge, if he faces a case and he cannot find it in written law, he must be able to find the law in the rules that live in society. This means that judges also have to understand about customary law. Customary law can be said to be the civil 
law of Indonesian society which regulates the personal and individual legal relationships between one person and another in the environment where he lives.

In the realm of politics and state administration in Indonesia, customary law and traditional leaders have a very large influence, this is considering the role of traditional leaders who still have influence in the movement of public opinion on social and political issues raised by the media. Someone who is promoted by a traditional figure has a big enough chance to be accepted in the area. It is in relation to the ability to lead opinion, that the role and existence of traditional leaders has undergone a slight anthropological shift, namely that they are not only tribal leaders / community leaders socially and adat asaja but also play a role as a political tool of interested parties. Customary leaders realize that they have a major influence on the opinion of the community in their area so that they can deliberately sell themselves to stir people's views on an issue of particular interest. Not only limited to government interests, but extends to other interests including industrialization, deforestation, agrarian and so on.

So in this case it can be understood that the position of customary law in the legal system in Indonesia has a constitutional position that is the same as the legal position generally applies in the life of the state in Indonesia, but what should be underlined there is also a difference between customary law and the law that applies to it. generally namely from the aspect of enforceability and shape. Where in this case the validity of customary law only applies to Indonesians and from its aspect, customary law is generally unwritten. Therefore, of course, according to the requirements for recognition, it is a shared obligation to always preserve customary law and the customary law community itself, so that the noble values of the nation can be saved from the lows of degradation due to globalization.

\section{REFERENSI}

Abdillah, Ubed. 2002. Politik Identitas Etnis "Pergulatan Tanda Tanpa Identitas". Yayasan Indonesiatera. Magelang.

Anasiru, R. 2011. Kebijakan Publik Dalam Konstelasi Paradigma Pembangunan Kesejahteraan Sosial. Otoritas: Jurnal Ilmu Pemerintahan, 1(1). 
Bayo , Longgina Novadona. 2010. Kuasa Adat atas Gereja dan Negara di Adonara. Tesis. UGM. Yogyakarta

Davidson, Jamie S dkk (ed), Emilius Ola Kleden \& Nina Dwisasanti (penerjemah), 2010. Adat dalam Politik Indonesia. Yayasan Pustakan Obor Indonesia. Jakarta

Dwipayana, Ari. 2004. Bangsawan dan Kuasa "Kembalinya Para Ningrat di Dua Kota".IRE Press. Yogyakarta.

Hardi, R. 2011. Persepsi Masyarakat Terhadap Kebijakan Politik di Kota Parepare. Otoritas: Jurnal Ilmu Pemerintahan, 1(1).

Polnaya, G. A., \& Darwanto. 2015. Pengembangan Ekonomi Lokal Untuk Meningkatkan Daya Saing Pada Ukm Ekonomi Kreatif Batik Bakaran Di Pati, Jawa Tengah. Jurnal Bisnis Dan Ekonomi, 22(Vol 22, No 1 (2015): Vol. 22 No. 1 2015), 1-10.

Pramono, T., Bramantyo, R. Y., Setiono, G. C., \& Suwadji, S. 2019. Peningkatan Kesejahteraan Masyarakat Melalui Program Kemitraan Perhutani Di Kecamatan Ngancar Kabupaten Kediri ( Studi Implementasi Peraturan Menteri Lingkungan Hidup dan Kehutanan No.P.83/MenLHK/Setjen/Kum.1/10/2016 Tentang Kemitraan Kehutanan). Transparansi Hukum, Vol. 2(No. 2).

Wahyuni, N. 2018. Perlindungan Hukum Bagi Konsumen Melalui Penyelesaian Sengketa Akibat Janji Iklan Perumahan. Transparansi Hukum, 1(1), 19-36. 